\title{
A Systematic Literature Review of the Application of Information Communication Technology for Visually Impaired People
}

\author{
Md Mahfuz Ashraf, ${ }^{1}$ Najmul Hasan, ${ }^{2}$ Lundy Lewis, ${ }^{3}$ Md Rashadul Hasan, ${ }^{4}$ and Pradeep Ray ${ }^{5}$ \\ ${ }^{1}$ School of Public Health and Community Medicine, University of New South Wales, Australia, \\ ${ }^{2}$ MRC Bangladesh Ltd, Dhaka, Bangladesh, \\ ${ }^{3}$ Southern New Hampshire University, United States of America, \\ ${ }^{4}$ Brainstorm Bangladesh Ltd, Dhaka, Bangladesh \\ ${ }^{5}$ WHO Collaborating Centre on e-Health, University of New South Wales, Australia
}

\begin{abstract}
T echnological advancement in general is providing better and cheaper solutions to assist the visually impaired (VI) community. Although information communication technology (ICT) has great potential to support the inclusion of VI people in educational, social and workforce settings, there are far fewer ICT projects for $\mathrm{VI}$ people compared to other projects. This systematic literature review provides our findings on the existing state of ICT projects and describes outstanding issues in ICT support of VI people. Based on our findings, we suggest increased collaboration among healthcare professionals, caregivers, programmers, engineers, as well as policy makers; and adoption of policies in future ICT projects for VI people. A wide search of seven journal databases found a relevant cross-section of articles that were published between 2010 and 2015. Software Zotero Standalone and EndNote were used to screen and maintain metadata. After the initial screening of 6993 titles, 683 abstracts were scrutinised, from which 55 full text articles were selected for final review. We analysed and synthesised 37 articles. Our findings show the progress, awareness, interest, and issues in ICT integration to improve the quality of life for VI people. Three emergent topics for VI people are (a) assistive technology, (b) e-accessibility, and (c) virtual interfaces. Our findings suggest that ICT-aided applications can bring positive changes for VI people. We advance several issues that should be addressed and further developed, collaboratively, to spread awareness and invoke new policies aimed to improve the quality of life of VI people.
\end{abstract}

Keywords: information communication technology (ICT), visually impaired (VI) people, systematic literature review, thematic analysis

According to the most recent survey by the World Health Organization (WHO), the number of visually impaired (VI) people in the world is 285 million, where approximately 39 million people are blind (Mariotti, 2012). Visual impairment includes both low vision and blindness (WHO, 2007). The majority of people with visual impairment (about 90\%) live in developing countries and about $65 \%$ are aged 50 or above (Mothiravally, Ang, Baloch, Kulampallil, \& Geetha, 2014). Only 14\% to $20 \%$ of people in developed countries suffer from disabilities in general, and these people have greater opportunities to take advantage of ICT-aided tools (Hogan, Kyaw-Myint, Harris, \& Denronden, 2012).
Numerous studies have been conducted focusing on people with disabilities from a sociological point of view. McAnaney and Williams (2010) suggest using action research methods for disability management. Hogan et al. (2012) contend that people with disabilities face significant inequity of remuneration, globally, due to the perception of a lack of skills and employment accommodations for particular roles. Niehaus and Marfels (2010) identify the key competencies of disabled people by using factor analysis and investigate the scope of their integration into the workforce and mainstream society. However, there are insufficient studies in the specific domain of ICT applications for VI people

Address for correspondence: Md Mahfuz Ashraf, Lecturer, School of Public Health and Community Medicine, University of New South Wales, Australia. E-mail: md.ashraf@unsw.edu.au 
and its potentially positive effect for VI people in the workforce.

Until now, various intervention programs have been conducted for VI people, and the diverse applications of ICT show promise in using ICT-aided tools. Governments in both developed and developing countries are finding ways to empower VI people through education, where a better quality life may be achieved by introducing new technology-related interventions. A pertinent question to ask is whether all countries should follow a 'one-size-fits-all' view of ICT-aided technologies or should countries attempt to build theories and frameworks based on their own cultural and sociopolitical and socioeconomic contexts. ICT scholars have suggested that the theories practised and the frameworks established in developed countries should be adopted in the ICT programs of under-industrialised or developing countries so that local researchers can work under the guidance of those frameworks (Ciborra, \& Navarra, 2005; Heeks, 2001; MacKenzie, Podsakoff, \& Podsakoff, 2011; Mbarika, Okoli, Byrd, \& Datta, 2005; Melville, 2010; Musa, Meso, \& Mbarika, 2005). At the same time, it would seem essential to have a contextbased, holistic view of the issues with ICT integration for VI people in order to find new perspectives and opportunities within the purview of those frameworks.

Many studies show that the use of ICT, such as the use of assistive technology, improves the productivity of people with a physical disability. Usually an assistive technology product can be equipment or a device, usually electronic or mechanical in nature, that helps disabled people to maintain their independence or improve their quality of daily life. Although most of the studies provide promise in maximising the benefits for the physically disabled or otherwise challenged people, studies related to the use of ICT for VI people are relatively less well documented in the academic field. Due to the rapid growth of professional publications, the identification of relevant studies and the synthesis of key concepts have become difficult. To overcome such problems during the identification and synthesis phase in our study, we conducted a systematic literature review (SLR) using specific search strategies. Our central focus is to understand the existing state of ICT-related products and discern the specific outstanding issues in the application of ICT for VI people. Therefore, this study aims to (a) analyse the existing research findings on ICT's role in the lives of VI people, and (b) identify the core ICT accessibility issues addressed in the existing literature.

\section{Systematic Literature Review}

The SLR is 'a means of evaluating and interpreting all available research relevant to a particular research question or topic area or phenomenon of interest' (Brereton, Kitchenham, Budgen, Turner, \& Khalil, 2007). A SLR mainly focuses on the difficulty of aggregating empirical evidence that might be procured by someone using widely different contexts and techniques (Webster \& Watson, 2002). Tranfield, Denyer, and Smart (2003), Keele (2007), and Dieste, Grimán, and Juristo (2009) identify the techniques for conducting an SLR, including selecting appropriate sources and keywords, combining the most favourable keyword strings using logical operators, identifying search areas for articles, and executing the search process to identify relevant empirical studies through screening based on specific inclusion and exclusion criteria.

Evaluating and following the guidelines of different SLR techniques (Chiarini, Ray, Akter, Masella, \& Ganz, 2013; Dieste et al., 2009; Kitchenham, 2004; Racine et al., 2012; Stuck et al., 1999; Vichitvanichphong, Kerr, Talaei-Khoei, \& Ghapanchi, 2013) in our review included three steps: (a) searching for the initial list of studies, (b) relevance appraisal, and (c) extracting data. The search process was implemented for seven specific databases to capture scholarly journal articles and conference proceedings across disciplines for the period 2010 to 2015 (see Table 1).

A thematic analysis was then conducted to find the main outcomes and contributions of these selected articles. Thematic analysis is often a subjective study and generally consists of in-depth information presented in the form of words (Wong, 2008). We used NVivo 10 qualitative data analysis software to find the clusters according to the similarity of most used words and phrases using constant comparison analysis, classical content analysis, keyword-in-context, word count, domain analysis, taxonomic analysis, and componential analysis (Leech \& Onwuegbuzie, 2011).

\section{Searching for the Initial List of Studies}

According to the International Statistical Classification of Diseases, Injuries, and Causes of Death (10th Revision) the definitions of low vision and blindness are as follows:

'Low vision' is defined as visual acuity of less than $6 / 18$ but equal to or
better than $3 / 60$, or a corresponding visual field loss to less than $20^{\circ}$, in
the better eye with the best possible correction. 'Blindness' is defined
as visual acuity of less than $3 / 60$, or a corresponding visual field loss
to less than $10^{\circ}$, in the better eye with the best possible correction.
'Visual impairment' includes both low vision and blindness. (WHO,
2007)

These definitions helped us to understand the broad area of research.

We used the following keywords search in each database so that the search result would provide articles containing the word 'technology' along with 'disabilities'. We used the following logical queries to search the full text of the journal articles and conference proceedings, where query intelligence is able to manage variations on words such as 'disability' and 'disabilities', 'impaired' and 'impairment' (i.e., 'disability' or 'visual 
TABLE 1

Keyword Database Searching Sumary

\begin{tabular}{|c|c|c|c|c|c|c|c|}
\hline \multicolumn{3}{|c|}{ Search Criteria } & \multicolumn{5}{|c|}{ Keywords* } \\
\hline & Field and & Document & & & ICT and & $\mathrm{ICT}$ & $I C T, V I$ \\
\hline Database & Access** & Type & Disabilities & $\mathrm{VI}$ & Disabilities & $\mathrm{VI}$ & and Impact \\
\hline Springer Link & All & Journal & 84,161 & 7,243 & 1,406 & 270 & 118 \\
\hline Science Direct & All & Journal & 83,899 & 9,593 & 829 & 118 & 90 \\
\hline Wiley Online Library & All & Journal & 60,607 & 6,506 & 1,524 & 181 & 99 \\
\hline IEEE Xplore & All & Journal & 121 & 503 & 13 & 303 & 48 \\
\hline ACM Digital Library & All & Journal & 6,133 & 2,298 & 877 & 194 & 78 \\
\hline CiteSeer & All & All & 165 & 14 & 0 & 0 & 0 \\
\hline Google Scholar & All & All & 230,000 & 27,400 & 14,500 & 8,580 & 6,560 \\
\hline Total & & & 465,086 & 53,557 & 19,149 & 9646 & 6993 \\
\hline
\end{tabular}

Note: * Total number of articles found by relevant keyword search in the period 2010 to 2015.

** Articles searched using all search criteria fields with full text and limited access.

impair', and 'information communication technology' or 'information technology', or 'information system' or 'technology', and 'impact' or 'result').

Seven online databases were searched for articles published from 2010 to 2015 to find the initial list of potentially relevant articles. The titles, keywords, abstract and full text were then carefully screened. The search query returned a total of 465,086 articles on disabilities but ultimately returned 6993 articles on ICT, VI, and the impact of ICT on VI people (see Table 1).

\section{Relevance Appraisal}

Relevant articles were then manually selected from the initial list and irrelevant articles were excluded by studying the titles, keywords, abstracts and full text. Articles that were removed from the list had one of the following exclusion criteria:

- The articles did not focus on technology.

- The articles were irrelevant to the VI community.

- The articles were duplicates.

- The articles did not agree with the inclusion criteria.

- The articles did not demonstrate empirical evidence.

- The articles were non-English articles.

- The articles were not published between 2010 to 2015.

- The outcomes of the articles were not related to VI people.

- The full text of the articles was not available.

- The articles did not meet the objective of our study.

\section{Extraction and Analysis of Data}

In the extraction stage, key details are considered to further identify articles based on inclusion and exclusion criteria for identifying relevant studies (Borg, Lantz, \& Gulliksen, 2014; Chaudhry et al., 2006; Racine et al.,
2012; Stuck et al., 1999), including deleting duplicate articles, year of publication, adoption, area of application, geographical area, type of communication, outcome measures, and results. Subsequently, 37 articles were identified and selected for further analysis (see Figure 1 for the exclusion steps).

The NVivo 10 software was used to identify the most frequently used words, and to cluster the 37 articles into autogenerated subthemes (see Appendix A). The subthemes were:

- assistive technology

- electronic accessibility

- mobile learning

- virtual interface

- access to the information

- robotic technology.

These subthemes were grouped into the three key themes for our research: (a) assistive technology, (b) eaccessibility, and (c) virtual interface (see Table 2 for subthemes).

\section{Results and Discussion}

This SLR synthesised the findings of the 37 separate studies (see Table 2) that met our inclusion criteria. Most of the selected studies are qualitative in nature (see Appendix B). Overall, the concepts of the selected studies varied: issues of awareness, usability, impact to the issues of personalisation, design and ease in accessibility (see Appendix A). Therefore, to aid the presentation of our synthesis of the existing research findings on ICT's role in the lives of VI people, and identifying the core ICT accessibility issues, our findings are provided in three key categories: (a) assistive technology, (b) e-accessibility, and (c) virtual interface. During the discussion of our findings from these articles, we highligh 


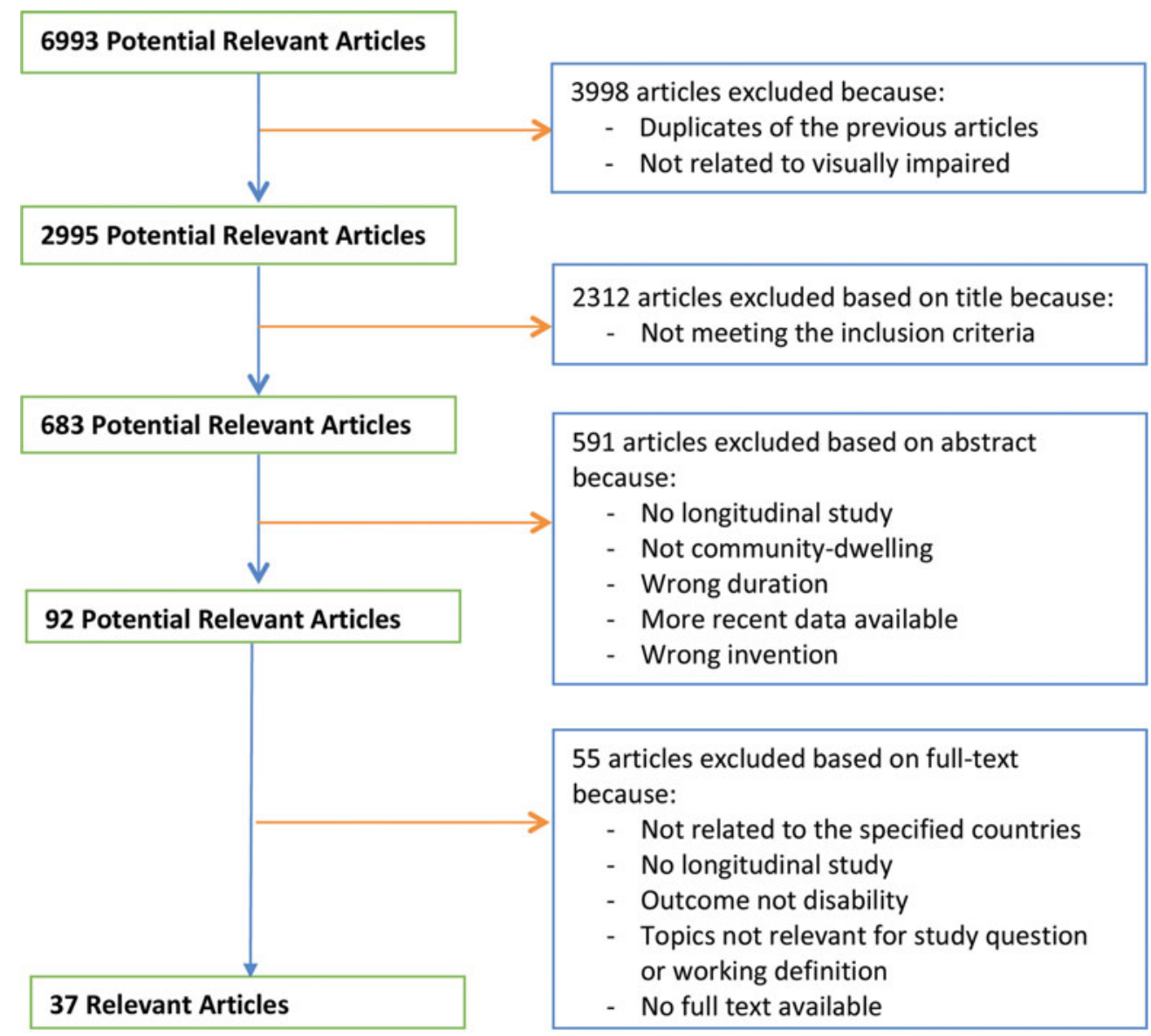

FIGURE 1

Steps in the inclusion and exclusion criteria.

the impact, demands, research gaps and limitations in the existing literature relevant to our research.

\section{Assistive Technology}

Assistive technology is any tool used to assist and improve the lives of people with disabilities. It is a broad concept (Grönlund, Lim, \& Larsson, 2010) and can be defined as 'any item, piece of equipment, product or system, whether acquired commercially, off-theshelf, modified or customised, that is used to increase, maintain or improve functional capabilities of individuals with cognitive, visual, physical or communication disabilities'. Assistive technology can improve the functional abilities of disabled people and help in rehabilitation. It can aid VI people by enabling them to interact with the environment using pointing devices, screen keyboards, dictionaries, and voice recognition systems. However, several studies have argued that such interactive devices can be more effective if designed according to the user's individual needs, strengths, weakness, and their sense of self-identity (Anuar, Karim, Shattar, \& Ali, 2015).

The study of Söderström and Ytterhus (2010) suggests that the use of assistive technology positively affects
VI people's self-identity and increases self-esteem when used with assistive technology-enabled tools (such as mobile apps, electronic braille systems) to overcome the barriers in accessing information. However, individual VI users may accept or reject an assistive technology device based on their own perception. Kanik (2014) suggests that every library and information centre should provide assistive technology to VI people (as such, many Turkish libraries use assistive technology for VI people and find it to be valuable and useful). Pal and Lakshmanan (2012) suggest that there should be government initiated subsidies or open-source assistive technology based on an in-depth study that identified prospects of assistive technology (such as social, educational, and workforce integration). Likewise, Borg, Larsson and Östergren (2011) advocate that it is an international and national responsibility to ensure that VI people can access and avail themselves of assistive technology. Therefore, access to assistive technology is important in the education of VI people.

Assistive technology-enabled devices can ease the difficulty in navigation for VI people (Lhotska, Stepankova, Pechoucek, Simak, \& Chod, 2011). The literature indicates that the use of multiple responses 
TABLE 2

Key Themes Derived From the Retrieved/Selected Articles

\begin{tabular}{|c|c|}
\hline Key Themes Used & Results and Conclusions \\
\hline Assistive technology & 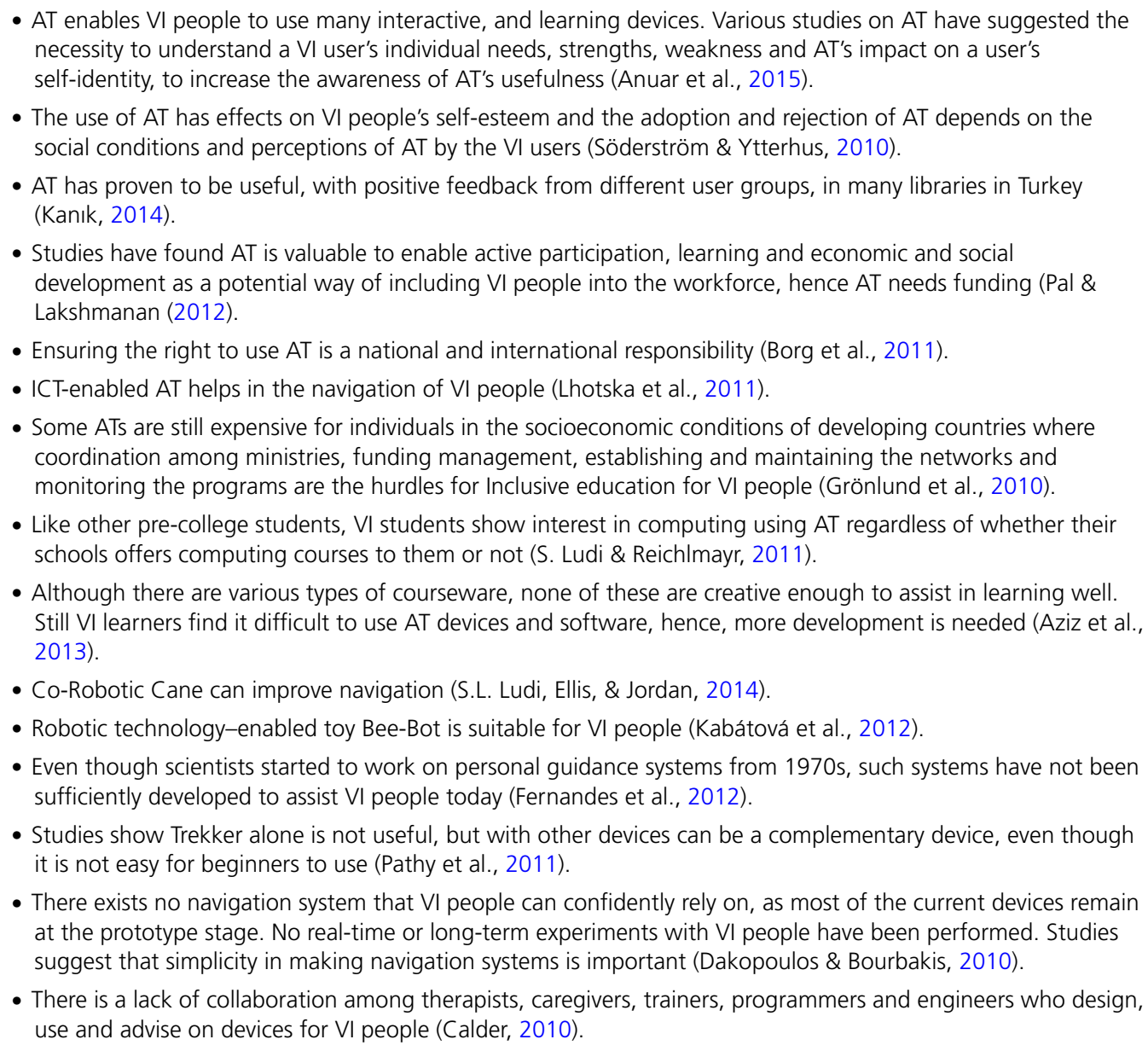 \\
\hline E-accessibility & $\begin{array}{l}\text { - E-accessibility supports VI people in learning (Laabidi et al., 2014; Singh, 2013). } \\
\text { - E-accessibility increases the integration of VI people into the educational system and workforce (Isaila \& Nicolau } \\
\text { 2010). } \\
\text { - E-accessibility is found to be helpful to empower VI people; it can help to overcome the educational gap, in } \\
\text { teaching and learning, if the digital disparity can be minimised (Singh, 2013). } \\
\text { - Intangible components such as, capacity-building and policymaking are important in minimising the learning } \\
\text { and digital disparity creating greater opportunities for the VI people (Samaniego et al., 2012). } \\
\text { - Personalised accessible learning environment aids VI people. VI people visit libraries despite their disability, thus } \\
\text { libraries need to provide services for VI students (Singh \& Moirangthem, 2010). } \\
\text { - E-accessibility affects the mood of VI people when they use websites; it increases their autonomy and } \\
\text { self-confidence; however, VI people complain when using e-accessibility because of their 'learned helplessness' } \\
\text { (Pascual et al., 2014). } \\
\text { - The existing technology can provide e-accessibility to access information by VI people; however, because of } \\
\text { economic reasons the specific needs of VI users are not considered in general (Bonavero, Huchard, \& Meynard, } \\
\text { 2014b). } \\
\text { - Software such as LaTex, BlindMath, Texeasier, LAMBDA and LeanMath provide better e-accessibility through } \\
\text { access overlays and hotkey techniques (Armano et al., 2014). } \\
\text { - Radios, voice recorders, CDs, and talking books are a cheaper alternative than e-accessibility solutions for VI } \\
\text { students (Bonnah et al., 2010). } \\
\text { - Several systems for shopping are available to assist VI people; however, blind buyers show less interest to buy } \\
\text { those devices in addition to the devices that they are already familiar with (Kulyukin \& Kutiyanawala, 2010). } \\
\text { - Some four or five star hotel websites are VI traveller friendly and help VI people to access information } \\
\text { (Mothiravally et al., 2014). }\end{array}$ \\
\hline
\end{tabular}


TABLE 2

Continued

\begin{tabular}{ll}
\hline Key Themes Used & Results and Conclusions \\
\hline - & Teachers need training on e-accessibility technology specific to VI students (Ramos \& Andrade, 2014). \\
- & Cooperation between teachers and students is important to suit the individual neeeds of a VI student when \\
& using e-accessibility (Carrière, 2012). \\
- & Regulation is needed to facilitate the development of ICT skills for VI people (Şimşek et al., 2010). \\
- & Locomotion interface helps its users to improve their performances providing better accuracy in estimating \\
Virtual interface & direction and depth of obstacles (Patel \& Vij, 2010). \\
- & Devices such as sensors, GPS receivers, or electronic compasses should be designed differently to cater to the \\
& varying needs of VI individuals (Strumillo, 2010). \\
- & Studies shows VI Facebook users participate in all the main social activities (Wu \& Adamic, 2014). \\
- & The government needs to enforce legislation to implement WCAG to safeguard the interests of blind people in \\
& relation to web accessibility when using a special user interface (Aziz et al., 2011). \\
- & Access overlay and improved spatial understanding can provide better user experiences for VI people when \\
& using touch screen technologies (Kane et al., 2011). \\
- & Mobile devices are great tools for e-inclusion of VI people. Designing a specific user interface for learning \\
& applications should be considered for accessibility and usability of VI people (Buzzi et al., 2012). \\
- & AlNIDIU can create a virtual environment that improves learning, and the user experience of VI people \\
& (Jadán-Guerrero, 2014). \\
- & Electronic travel aids are still at the prototype stage (Bujacz et al., 2011).
\end{tabular}

Note: $A T=$ assistive technology; ICT = information communication technology; $\mathrm{VI}=$ visually impaired; WCAG = web content accessibility guidelines.

obtained through assistive technology-enabled sensory inputs can assist persons in engaging in everyday activities (e.g. supporting children as they take part in various activities, reducing the negative impact of their impairment, and aiding them to yield better learning outcomes). In addition, some devices can provide information on the activity patterns of individual VI people. Grönlund et al. (2010) highlight the positive impact on the quality of life of VI people when assistive technology is used in inclusive education. However, assistive technology is still expensive considering the socioeconomic conditions of developing countries and as such assistive technology projects require both government and non-government funding, and active monitoring.

While learning is very challenging for VI people, there exist various types of learning software and assistive technology-enabled educational content for specific educational processes for VI students. VI students show eagerness in computing courses using assistive technology even though many of their educational facilities do not offer courses on computing (S. Ludi \& Reichlmayr, 2011). However, Aziz, Mutalib, Sarif, and Jaafar (2013) argue that computer-based learning applications are not designed well enough for effective learning among VI students. Technologies such as screen readers and vocal synthesis are useful for VI people, albeit too generic.

Robotic technology also has become popular as an aid to VI persons. Assistive robots are being adapted for use by VI people. There are various research projects that are involved in the designing, constructing, implementing and testing of robots to guide VI people through daily tasks; some e-learning technologies aim to automatically generate accessible content for VI students.

Co-Robotic Cane (CRC), an ICT project for VI, has been established to develop a co-robotic navigation aid that will improve a VI person's independent mobility and quality of life (S.L. Ludi, Ellis, \& Jordan, 2014). BeeBot, a programmable toy, has been found to be suitable for VI students (Kabátová, Jašková, Lecký, \& Laššáková, 2012). A device named BrainPort is being developed by neuroscientists and will be used for visual data collection through a small digital video camera. A new technology, a bionic eye or an artificial eye, which is a retinal system designed to restore vision, has the potential to improve the lives of VI people.

Even though the concept of a personal guidance system has existed since the 1970s, scientists have not yet perfected the technology for practical use (Fernandes et al., 2012). A device known as Trekker, which uses a global positioning system (GPS) to guide VI people in moving, is not sufficiently reliable because GPS is not available everywhere. Trekker is not easy to use and has to be used along with a white cane (Pathy, Noh, Moslin \& Subari, 2011). In another study, Dakopoulos and Bourbakis (2010) argue that assistive technologyenabled navigation systems are in a prototype stage, but are not reliable. Researchers are working on a low cost smartphone version that a blind person would use when walking around a building. Another study by Calder (2010) stresses that there is poor collaboration among therapists, caregivers, trainers, programmers, and engineers who contribute to the design and development of such devices for VI people. 


\section{E-accessibility}

E-accessibility is an effective tool at individual, community, national, and global levels. Access to information helps disabled people to manage their social contacts, coordinate their social events, and share their experiences and feelings. It has been reported that personalised and affordable e-accessible technologies support the learning process for people with visual impairment (Laabidi, Jemni, Jemni Ben Ayed, Ben Brahim, \& Ben Jemaa, 2014; Singh, 2013; an internet library project was designed to provide access to online information and services for VI persons). Isaila and Nicolau (2010) argue that e-accessibility offers many opportunities for people with special needs that are unavailable through other media, and that VI people using this media can be effectively integrated into the education system, labour market, and greater society.

Research shows that e-accessibility can act as an agent to transform the teaching and learning process to empower VI people. Singh (2013) finds that eaccessibility can assist VI people in transportation and communication. This study shows that the digital divide in e-accessibility can be decreased using optimised font size, colour and contrast, test recognising software, integrated GPS systems, screen readers, clear audio, text to speech books, and large button phones. The United Nations Educational, Scientific and Cultural Organization (UNESCO) has always advocated for the importance of the 'intangible' components of ICT, such as policies and capacity-building. Addressing these components can fundamentally minimise the digital-disparity in learning for VI people (Samaniego, Laitamo, Valerio, \& Francisco, 2012).

Singh and Moirangthem (2010) suggest that libraries, as a source of information and knowledge empowerment, need special initiatives to ensure services for VI students. Pascual, Ribera, Granollers, and Coiduras (2014) also found that VI users have better experiences and find self-confidence when websites are optimised to be used by them independently; however, web designers are less interested in such design due to cost and VI users do not complain if websites are not designed for them because of 'learned helplessness'. Another study reveals that VI students show great attraction to online courses because they are not identified as different from others. Unfortunately, website designers rarely offer web access optimised for VI people because of economic and financial barriers (Bonavero, Huchard, \& Meynard, 2014a).

Armano, Capietto, Illengo, Murru, and Rossini (2014) found that software such as LaTex, BlindMath, Texeasier, LAMBDA and LeanMath offers better eaccessibility experiences and solutions to VI people through access overlays, speech synthesis, and hotkey techniques that ultimately make users more independent and self-confident. However, radios, voice recorders, CDs and talking books are less costly solutions for e-accessibility (Bonnah, Nkansah, \& Unwin, 2010).

Kulyukin and Kutiyanawala (2010) found that even though some devices assist VI people in relation to instore navigation and product shopping, none of these meet all requirements. Further, VI people are less interested in buying newer technology to replace devices they are already using. VI travellers state that during travel they have to preplan extensively and they have to depend on others for information. A study in Malaysia shows VI travellers find it helpful when websites are user friendly and optimised for them (Mothiravally et al., 2014).

The advent of e-learning has brought more prospects in e-accessibility for VI people. It provides an open and flexible learning environment for VI people who have limited mobility; however, there is currently a lack of platforms optimised for VI.

In the process of providing e-accessibility, teachers also require training to make the technology available and useful for VI students (Ramos \& Andrade 2014). Carrière (2012) emphasises the cooperation between teachers and students necessary for the effective use of e-accessibility where mobile-based education is a new strategy for learning and teaching VI people. E-accessibility can ensure equal opportunity for VI people, and the provision of different and customised mobile learning approaches shows promise. Also, mobile tools and platforms are lower in cost than computerbased platforms. In another study, Şimşek, Altun and Ateş (2010) stress the importance of enacting governmental regulations to ensure e-accessibility.

\section{Virtual Interface}

Virtual interface or virtual environment is a significant medium through which VI users can interact with the web and the world. Until recently, there has been an apprehension that equality in accessibility was not being reached, and that graphical information in particular was not easily accessible to blind users. Some researchers suggest that a virtual environment is potentially suitable to explore greater scope for VI users, reducing their dependency on guides, and aiding in the development of more accurate spatial maps. Virtual environment techniques such as BlindAid enable VI people to learn about new environments on their own. Likewise, locomotion interfaces for VI users show improved performance in walking (Patel \& Vij, 2010). A study by Strumillo (2010) shows that the use of GPS receivers or electronic compasses to provide a virtual environment can aid VI people; however, such guidance systems need to be optimised separately for different VI users, and information received through other senses should fulfil the lack of the visual channel at the perceptual level. 
Wu and Adamic (2014) show that VI Facebook users have an equal eagerness to participate in social interactions. By using virtual interfaces on web pages, VI people can access information using a standard web browser with a Java virtual machine. Therefore, website designers need to incorporate accessibility criteria to ensure that VI people can access their websites. Aziz, Isa, and Fadzir (2011) point out the need for governmental regulations to serve the interest of VI users by enforcing web content accessibility guidelines (WCAG) to provide a special user interface.

Kane et al. (2011) found that access overlay and improved spatial understanding can provide a better user interaction when using a touch screen. Buzzi, Buzzi and Leporini (2012) suggest that designing customised and optimised user interfaces for mobile devices and applications will increase the inclusion of VI people. A study by Jadán-Guerrer (2014) finds that AINIDIU (intelligent agent for VI children) can create an entertainment-education environment that improves the learning and the user experience of VI people. Also, different electronic travel aids using 3D virtual environments show promise; however, these devices are not yet commercially available (Bujacz, Skulimowski, \& Strumillo, 2011).

\section{Conclusions}

Based on the selected 37 articles, a mix of dynamic findings (see Appendix B) have been identified that fall into three distinctive technical themes (Appendix A). These themes are derived from our literature analysis using thematic analysis, which required categorising and analysing articles according to themes that were relevant to the goals of a study. According to our research goal, we reviewed the article findings from the perspective of ICT's role in the lives of VI people, and identifying the core ICT accessibility issues, such as issues related to economic and social barriers.

Our review finds that the study of ICT for VI people still requires further research and investigation, although our systematic review provides evidence of increasing interest in further research. In adiditon, from the information gained from international conferences, researchers and various bodies, there has been emphasis on ICT accessibility for VI people, such as making friendlier websites (Fuglerud, 2011; Wanniarachchi \& Jayathilake, 2012), which has highlighted the need for a greater development responsibility for web content providers.

Our study identifies various advancements and issues related to the application of ICT for VI people. It is difficult to provide definitive conclusions and recommendations that apply to the entire VI community because there are various and ever-changing social contexts in which VI people live (Söderström \& Ytterhus, 2010). For example, assistive technology helps to bring equal opportunities and minimise digital-disparity by using ICT-led technologies; however, economic disparity in developing countries may limit this minimisation process of digital-disparity. Therefore for future research, it would not be appropriate to compare, contrast and superimpose the results and issues found in our study across all developing countries.

Our review shows that assistive technology can affect a VI person's self-esteem, and the adoption or rejection of the technology depends on the social conditions and perceptions of its specific users (e.g., in some countries the use of technological devices is considered to be a symbol of 'high status'). Therefore, while making plans and policies for the use of assistive technology, we should strive to change such perceptions so that devices are deemed as essential devices to be used by all types of people.

This study reveals that VI people show less interest in purchasing a new device to replace devices with which they are already familiar. In such cases, it might be useful to distinctly and easily show opportunities to use such devices and discuss benefits that any new device might provide to the VI device user. We also found that development of assistive technology for VI people is relatively slow and governments in developed countries should formulate and approve policies to expedite research and development of assistive technology for VI people.

In the case of e-accessibility, the main concern is the cost that impedes the wider availability of e-accessibility in developing countries where unequal distribution of resources is traditionally predominant. It is essential to explore how government can play a vital role to ensure the affordability of e-accessibility. Additionally, mobile learning platforms are of great interest to VI people; however, there is currently a lack of professional expertise in this field to further develop these platforms. Virtual interfaces also can reduce dependency on guides for VI people and help them with more accurate spatial maps and strategies. Such technology requires a wide coverage of GPS systems and cheap internet access, which in turn requires governmental support.

This study has not quantitatively assessed the impact of ICT on the lives of VI people; for example, this study has not determined the percentage of VI people who have benefited from the adoption of ICT, the percentage of their increased involvement in the workforce, or the increment in productivity, income, and contribution to the economy. However, our study provides the basis for researchers and policymakers to identify the important aspects of the planning and materialising of ICT projects that are aimed at improving the quality of life for VI people.

Last, but not least in our opinion, is the understanding of 'contextual analysis' in future research that is essential prior to the deployment and provision of 
technologies for VI people (Vidhya \& Kumari, 2015). For instance, a society should accept and recognise the expertise of a VI person who learns through computeraided technology in the rural settings of a developing country. Therefore, existing technologies can serve as a good starting point for further research to investigate how ICT-led innovation and adoption into the life of people with VI is considered in different countries.

\section{References}

Anuar, J., Karim, N.A., Shattar, N.A., \& Ali, F.M. (2015). Accessibility of people with disabilities on hospitality braille products. Journal of Applied Environmental and Biological Sciences 5, 5-8.

Armano, T., Capietto, C., Illengo, M., Murru, N., \& Rossini, R. (2014). An overview on ICT for the accessibility of scientific texts by visually impaired students. Presented at the conference proceedings of the La Società Italiana di Ricerca sull'Educazione Mediale (SIREM) e la Società Italiana di e-Learning (Sie-L), November 13-15, 2014.

Aziz, M.A., Isa, W.A.R.W. M., \& Fadzir, N.S.M. (2011). Accessibility of websites for people with disabilities (PWD) in Malaysia: An empirical investigation. International Journal on Advanced Science, Engineering and Information Technology, 1(2), 221-226.

Aziz, N., Mutalib, A.A., Sarif, S. M., \& Jaafar, M.S. (2013). Preliminary investigation on creative educational content for visuallyimpaired (VI) learners advances in visual informatics (pp. 408417): Springer.

Bonavero, Y., Huchard, M., \& Meynard, M. (2014a). Web page personalization to tmprove e-accessibility for visually impaired people. Paper presented at the WEB 2014, The Second International Conference on Building and Exploring Web Based Environments.

Bonavero, Y., Huchard, M., \& Meynard, M. (2014b). Web page personalization to improve e-accessibility for visually impaired people. Paper presented at the WEB 2014: The Second International Conference on Building and Exploring Web Based Environments.

Bonnah, Nkansah, G., \& Unwin, T. (2010). The contribution of ICTs to the delivery of special educational needs in Ghana: practices and potential. Information Technology for Development, 16(3), 191-211.

Borg, J., Lantz, A., \& Gulliksen, J. (2014). Accessibility to electronic communication for people with cognitive disabilities: A systematic search and review of empirical evidence. Universal Access in the Information Society. doi: 10.1007/s10209-014-0351-6

Borg, J., Larsson, S., \& Östergren, P.-O. (2011). The right to assistive technology: For whom, for what, and by whom. Disability and Society, 26(2), 151-157. doi: 10.1080/09687599.2011.543862

Brereton, P., Kitchenham, B.A., Budgen, D., Turner, M., \& Khalil, M. (2007). Lessons from applying the systematic literature review process within the software engineering domain. Journal of Systems and Software, 80(4), 571-583. doi: 10.1016/j.jss.2006.07.009

Bujacz, M., Skulimowski, P., \& Strumillo, P. (2011). Sonification of 3D scenes using personalized spatial audio to aid visually impaired persons. Paper presented at the International Conference on Auditory Display, Budapest, Hungary.

Buzzi, M.C., Buzzi, M., \& Leporini, B. (2012). Investigating mobile learning and accessibility for blind users. Coference proceedings of the International Symposium on Mobile Learning for Visually Impaired People, May 25, 2012.

Calder, D.J. (2010). Assistive technologies and the visually impaired: a digital ecosystem perspective. Proceedings of PETRA 2010, Article 1. http://doi.org/10.1145/1839294.1839296
Carrière, V. (2012). ICT and cooperation in learning/teaching in visually handicapped situation. Procedia - Social and Behavioral Sciences, 46, 701-705. doi: 10.1016/j.sbspro.2012.05.184

Chaudhry, B., Wang, J., Wu, S., Maglione, M., Mojica, W., Roth, E., . S Shekelle, P.G. (2006). Systematic review: impact of health information technology on quality, efficiency, and costs of medical care. Annals of Internal Medicine, 144(10), 742752.

Chiarini, G., Ray, P., Akter, S., Masella, C., \& Ganz, A. (2013). mHealth technologies for chronic diseases and elders: A systematic review. Selected Areas in Communications, IEEE Journal, 31(9), 6-18.

Ciborra, C., \& Navarra, D.D. (2005). Good governance, development theory, and aid policy: Risks and challenges of egovernment in Jordan. Information Technology for Development, 11(2), 141-159.

Dakopoulos, D., \& Bourbakis, N.G. (2010). Wearable obstacle avoidance electronic travel aids for blind: A survey. Systems, Man, and Cybernetics, Part C: Applications and Reviews, IEEE Transactions, 40(1), 25-35.

Dieste, O., Grimán, A., \& Juristo, N. (2009). Developing search strategies for detecting relevant experiments. Empirical Software Engineering, 14(5), 513-539.

Fuglerud, K.S. (2011, July). The barriers to and benefits of use of ICT for people with visual impairment. In International Conference on Universal Access in Human-Computer Interaction (pp. 452462). Berlin, Germany: Springer.

Fernandes, H., Conceição, N., Paredes, H., Pereira, A., Araújo, P., \& Barroso, J. (2012). Providing accessibility to blind people using GIS. Universal Access in the Information Society, 11(4), 399407.

Grönlund, Å., Lim, N., \& Larsson, H. (2010). Effective use of assistive technologies for inclusive education in developing countries: Issues and challenges from two case studies. International Journal of Education and Development using ICT, 6(4), 5-26.

Heeks, R.B. (2001). 'What did Giddens and Latour ever do for us?'. Information Technology in Developing Countries, 11(1), 1-5.

Hogan, A., Kyaw-Myint, S.M., Harris, D., \& Denronden, H. (2012). Workforce participation barriers for people with disability. International Journal of Disability Management, 7, 1-9.

Isaila, N., \& Nicolau, I. (2010). Promoting computer assisted learning for persons with disabilities. Procedia - Social and Behavioral Sciences, 2(2), 4497-4501.

Jadán-Guerrero, J. (2014). An experience of technology transfer success of software for children with disabilities. CLEI Electronic Journal, 17(2), 5-5.

Kabátová, M., Jašková, L., Lecký, P., \& Laššáková, V. (2012). Robotic activities for visually impaired secondary school children. Paper presented at the 3rd International Workshop, Teaching Robotics, Teaching with Robotics.

Kane, S.K., Morris, M.R., Perkins, A.Z., Wigdor, D., Ladner, R.E., \& Wobbrock, J.O. (2011). Access overlays. Proceedings of the 24th Annual ACM Symposium on User Interface Software and Technology — UIST '11, 273. http://doi.org/10.1145/2047196. 2047232

Kanık, L. (2014). Assistive technology and education laboratory for individuals with visual disabilities (GETEM). Qualitative \& Quantitative Methods in Libraries.

Keele, S. (2007). Guidelines for performing systematic literature reviews in software engineering Technical report, Ver. 2.3 EBSE Technical Report. EBSE.

Kitchenham, B. (2004). Procedures for performing systematic reviews. Keele University Technical Report TR/SE-0401, and NICTA Technical Report 0400011T.1. 
Kulyukin, V., \& Kutiyanawala, A. (2010). Accessible shopping systems for blind and visually impaired individuals: Design requirements and the state of the art. The Open Rehabilitation Journal, 3, 158-168.

Laabidi, M., Jemni, M., Jemni Ben Ayed, L., Ben Brahim, H., \& Ben Jemaa, A. (2014). Learning technologies for people with disabilities. Journal of King Saud University - Computer and Information Sciences, 26(1), 29-45. doi: 10.1016/j.jksuci.2013.10.005

Leech, N.L., \& Onwuegbuzie, A.J. (2011). Beyond constant comparison qualitative data analysis: Using NVivo. School Psychology Quarterly, 26(1), 70.

Lhotska, L., Stepankova, O., Pechoucek, M., Simak, B., \& Chod, J. (2011). ICT and eHealth projects. Paper presented at the Telecom World (ITU WT), 2011 Technical Symposium at ITU.

Ludi, S., \& Reichlmayr, T. (2011). The use of robotics to promote computing to pre-college students with visual impairments. ACM Transactions on Computing Education (TOCE), 11(3), 20.

Ludi, S.L., Ellis, L., \& Jordan, S. (2014). An accessible robotics programming environment for visually impaired users. Paper presented at the Proceedings of the 16th international ACM SIGACCESS conference on Computers \& accessibility.

MacKenzie, S.B., Podsakoff, P.M., \& Podsakoff, N.P. (2011). Construct measurement and validation procedures in MIS and behavioral research: Integrating new and existing techniques. MIS quarterly, 35(2), 293-334.

Mariotti, S.P. (2012). Global data on visual impairments 2010. Geneva, Switzerland: World Health Organization.

Mbarika, V.W.A., Okoli, C., Byrd, T.A., \& Datta, P. (2005). The neglected continent of is research: A research agenda for subSaharan Africa. Journal of the Association for Information Systems, 6(5), 130-170.

McAnaney, D., \& Williams, B. (2010). Internalising disability management: Using action research to explore organisational change processes. International Journal of Disability Management, 5(02), 32-39.

Melville, N.P. (2010). Information systems innovation for environmental sustainability. MIS quarterly, 34(1), 1-21.

Mothiravally, V., Ang, S., Baloch, G.M., Kulampallil, T.T., \& Geetha, S. (2014). Attitude and perception of visually impaired travelers: A case of Klang Valley, Malaysia. Procedia - Social and Behavioral Sciences, 144, 366-377. http://doi.org/10.1016/j.sbspro. 2014.07.306

Musa, P.F., Meso, P., \& Mbarika, V.W. (2005). Toward sustainable adoption of technologies for human development in sub-saharan africa: precursors, diagnostics, and prescriptions. Communications of AIS, 2005(15), 592-608.

Niehaus, M., \& Marfels, B. (2010). Competencies and tasks of disability management professionals in Germany. International Journal of Disability Management, 5(02), 67-72.

Pal, J., \& Lakshmanan, M. (2012). Assistive technology and the employment of people with vision impairments in India. Paper presented at the Proceedings of the Fifth International Conference on Information and Communication Technologies and Development.

Pascual, A., Ribera, M., Granollers, T., \& Coiduras, J.L. (2014). Impact of Accessibility Barriers on the Mood of Blind, Lowvision and Sighted Users. Procedia - Computer Science, 27, 431440. doi: 10.1016/j.procs.2014.02.047

Patel, K.K., \& Vij, S.K. (2010). Unconstrained walking plane to virtual environment for spatial learning by visually impaired. Ubiquitous Computing and Communication Journal.

Pathy, N.B., Noh, N.M., Moslin, S.I., \& Subari, M.D.B. (2011). Space technology for the blind and visually impaired. Paper presented at the Space Science and Communication (IconSpace), 2011 IEEE International Conference.

Racine, M., Tousignant-Laflamme, Y., Kloda, L.A., Dion, D., Dupuis, G., \& Choinière, M. (2012). A systematic literature review of 10years of research on sex/gender and experimental pain perception-Part 1: Are there really differences between women and men? Pain, 153(3), 602-618.

Ramos, S.I.M., \& de Andrade, A.M.V. (2014). ICT in Portuguese reference schools for the education of blind and partially sighted students. Education and Information Technologies, 1-17.

Samaniego, P., Laitamo, S.M., Valerio, E., \& Francisco, C. (2012). Report on using information and communication technologies (ICTs) in education for persons with disabilities.

Şimşek, Ö., Altun, E., \& Ateş, A. (2010). Developing ICT skills of visually impaired learners. Procedia - Social and Behavioral Sciences, 2(2), 4655-4661. doi: 10.1016/j.sbspro.2010.03.745

Singh, J. (2013). Exploiting ICT for empowering people with disabilities (PWDs). Indian Journal of Inclusive Growth, 1(1), 113119.

Singh, K., \& Moirangthem, E. (2010). Are Indian libraries VIPfriendly? Information use and information seeking behaviour of visually impaired people in Delhi libraries. Library Philosophy and Practice (e-journal), 374.

Söderström, S., \& Ytterhus, B. (2010). The use and non-use of assistive technologies from the world of information and communication technology by visually impaired young people: A walk on the tightrope of peer inclusion. Disability \& Society, 25(3), 303-315. doi: 10.1080/09687591003701215

Strumillo, P. (2010). Electronic interfaces aiding the visually impaired in environmental access, mobility and navigation. Paper presented at the Human System Interactions (HSI), 2010 3rd Conference.

Stuck, A.E., Walthert, J.M., Nikolaus, T., Büla, C.J., Hohmann, C., \& Beck, J.C. (1999). Risk factors for functional status decline in community-living elderly people: a systematic literature review. Social Science \& Medicine, 48(4), 445-469.

Tranfield, D.R., Denyer, D., \& Smart, P. (2003). Towards a methodology for developing evidence-informed management knowledge by means of systematic review. British journal of management, 14, 207-222.

Vichitvanichphong, S., Kerr, D., Talaei-Khoei, A., \& Ghapanchi, A.H. (2013). Analysis of research in adoption of assistive technologies for aged care. Paper presented at the Proceedings of the 24th Australasian Conference on Information Systems 2013.

Vidhya, P., \& Kumari, J. (2015). ICT based learning tools and its impact on students with visual Impairment. International Journal of Computer Science and Information Technology \& Security, 396398.

Wanniarachchi, H., \& Jayathilake, D. (2012, December). A framework for building web sites that are friendly to visually impaired. In advances in ICT for Emerging Regions (ICTer), 2012 International Conference (pp. 103-110).

Webster, J., \& Watson, R.T. (2002). Analyzing the past to prepare for the future: Writing a literature review. Management Information Systems Quarterly, 26(2), 3.

Wong, L. (2008). Data analysis in qualitative research: A brief guide to using NVivo. Malaysian Family Physician: the Official Journal of the Academy of Family Physicians of Malaysia, 3(1), 14.

World Health Organization. (2007). Global initiative for the elimination of avoidable blindness: Action plan 2006-2011. Geneva, Switzerland: Author.

Wu, S., \& Adamic, L. (2014). Visually impaired users on an online social network. Proceedings of the 32nd Annual ACM Conference, pp. 3133-3142. http://doi.org/10.1145/2556288.255741 


\section{Appendix A}

\section{Sources Clustered by Word Use and Frequency, and Themes}

We clustered the most used words and their frequency in the selected 37 articles in NViVo10. This clustering is illustrated in Figure A1 by the different colour coding of author(s).

\section{Subthemes}

We categorised relevant concepts/statements from the clustered articles in Figure A1. These concepts were further organised into subthemes and key themes in the process of analysis (see Table A1).

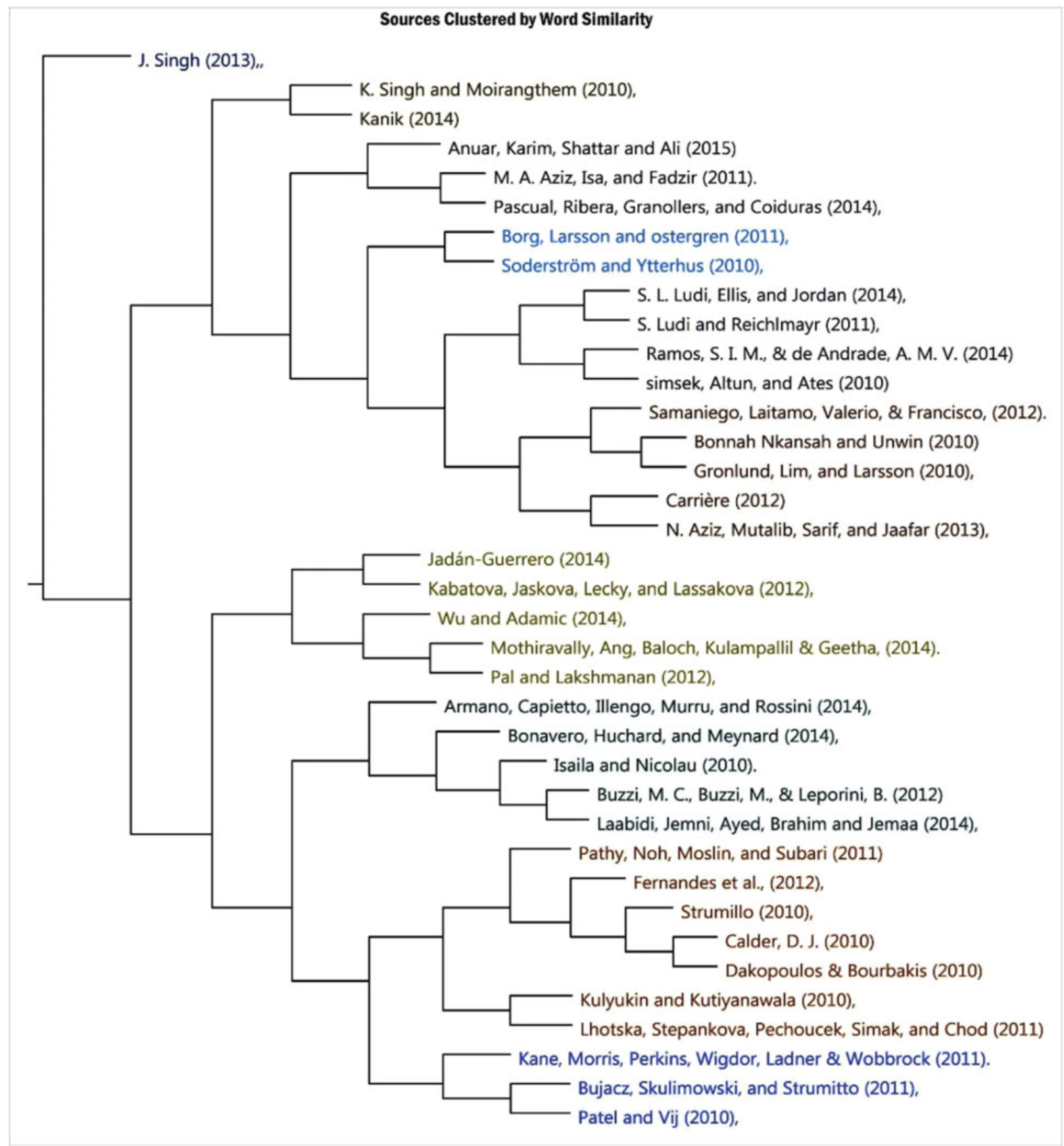

FIGURE A1

Clustered articles to similar words/concepts. 
TABLE A1

Related Concepts, Subthemes and Key Themes

\begin{tabular}{lll}
\hline Related Concepts Generated From Search/Keyword & Subthemes & Key theme \\
\hline Personalisation to improve e-accessibility & - E-accessibility & E-accessibility \\
Universal design & - Access to information & - E-learning \\
Government awareness & \\
Improving e-accessibility & \\
It is possible to print both braille and ink by using e-accessibility & \\
VI people access to the graphical interface electronically & - Robotic technology \\
Online accessibility and information needs & - Transferred technology & Assistive technology \\
Impacts of technology on jobs for people with disabilities & - Assistive technology \\
Use of sssistive technology most directly impacted the idea & \\
impaired development & \\
Technology for students with visual impairments & \\
Implementation of AT with students who are VI & \\
Conceptualization and measurement of assistive & - Space technology \\
technology usability & - 3-D navigation \\
Virtual sound sources for visual impaired & \\
Virtual 3D environment & \\
Acoustic virtual reality for transactions on neural sense & \\
Web-based mapping and virtual reality technologies & \\
Incorporation of a virtual character & Virtual interface \\
Becoming virtual friend & \\
Virtual platform for work &
\end{tabular}

\section{Appendix B}

\section{Summary of ICT Application and Its Impact on Visually Impaired People}

\begin{tabular}{|c|c|c|c|}
\hline Author(s) & Aims/Objectives of Study & Methods & Research Findings \\
\hline $\begin{array}{l}\text { Grönlund et al. } \\
\text { (2010) }\end{array}$ & $\begin{array}{l}\text { To find how AT can be effectively } \\
\text { used for inclusive education in } \\
\text { developing countries, including } \\
\text { VI people. }\end{array}$ & $\begin{array}{l}\text { Conducted an in-depth case study } \\
\text { of two developing countries } \\
\text { Bangladesh and Tanzania. }\end{array}$ & $\begin{array}{l}\text { - To overcome the obstacles of what types } \\
\text { of coordination is needed for AT was } \\
\text { identified. } \\
\text { - Provided a comprehensive view of } \\
\text { inclusive education to different } \\
\text { stakeholders. }\end{array}$ \\
\hline $\begin{array}{l}\text { Lhotska et al. } \\
\text { (2011) }\end{array}$ & $\begin{array}{l}\text { To present existing solutions in ICT } \\
\text { that can be advantageously } \\
\text { applied to the healthcare } \\
\text { domain, (e.g., solutions for the } \\
\text { blind). }\end{array}$ & $\begin{array}{l}\text { A survey method was used to fulfil } \\
\text { the objective. }\end{array}$ & $\begin{array}{l}\text { - Successful applications need the coherent } \\
\text { approach of experts from many different } \\
\text { disciplines, such as health. } \\
\text { - Localisation and navigation for VI people. } \\
\text { - ICT helping disabled and elderly. }\end{array}$ \\
\hline $\begin{array}{l}\text { Dakopoulos \& } \\
\text { Bourbakis } \\
\text { (2010) }\end{array}$ & $\begin{array}{l}\text { To develop a wearable device that } \\
\text { can convert visual information } \\
\text { into a tactile signal that will } \\
\text { assist VI people in self-navigation } \\
\text { as they face obstacles. }\end{array}$ & $\begin{array}{l}\text { A survey to study and compare the } \\
\text { portable obstacle detection } \\
\text { systems so that the researchers } \\
\text { and users can learn about the } \\
\text { different capabilities of these } \\
\text { devices, and understand how } \\
\text { current AT aid VI people. }\end{array}$ & $\begin{array}{l}\text { - How the portable devices positively affect } \\
\text { the life of VI people. } \\
\text { - After implementing the system and } \\
\text { device, a real-time experience can be } \\
\text { monitored and experienced. }\end{array}$ \\
\hline $\begin{array}{l}\text { Söderström \& } \\
\text { Ytterhus } \\
\text { (2010) }\end{array}$ & $\begin{array}{l}\text { Study the core merits and uses of } \\
\text { AT in the life of VI people and as } \\
\text { a part of ICT. }\end{array}$ & $\begin{array}{l}\text { Qualitative study using } \\
\text { semistructured and face-to-face } \\
\text { interviews with a focused } \\
\text { sample size. }\end{array}$ & $\begin{array}{l}\text { - In most of the cases studied, young } \\
\text { people adopted and used communication } \\
\text { tools. } \\
\text { - AT has positive effects on a user's } \\
\text { self-identity. } \\
\text { - ICT and AT have two greatly distinct and } \\
\text { incompatible characteristics. }\end{array}$ \\
\hline
\end{tabular}


Continued

\begin{tabular}{|c|c|c|c|}
\hline Author(s) & Aims/Objectives of Study & Methods & Research Findings \\
\hline $\begin{array}{l}\text { Şimşek et al., } \\
\text { (2010) }\end{array}$ & $\begin{array}{l}\text { To find solutions for the general } \\
\text { problems that the VI learners face } \\
\text { when developing their ICT skills. }\end{array}$ & $\begin{array}{l}\text { Qualitative descriptive case studies, } \\
\text { observations and interview } \\
\text { techniques were used. A 'behaviour } \\
\text { checklist' was used for each } \\
\text { observation as a standard tool. }\end{array}$ & $\begin{array}{l}\text { - Three different skills — basic } \\
\text { operating system skill, word } \\
\text { processing skill, and internet } \\
\text { useage skill - were considered } \\
\text { as ICT skills that were developed } \\
\text { from watching video clips for VI } \\
\text { learners. }\end{array}$ \\
\hline
\end{tabular}

Singh (2013) To ensure the access to information for $\mathrm{VI}$ people, also promoting access for people with disabilities to new information and communications technologies and systems, including the internet.

Laabidi et al. To cover basic concepts of (2014) e-accessibility, universal design and AT, with a special focus on accessible-learning systems.

Kanık (2014)

To provide access to information services for individuals with visual disabilities.

Isaila \& Nicolau (2010)

Bonavero et al. (2014b)

Patel \& Vij (2010) To describe a uniquely simple treadmill-style locomotion interface that uses a manual treadmill with handles to provide need-based support, thus allowing walking with assured stability. (n) and e-Learning standards in creating web sites or assistive software providing solutions for access to learning objects.

The aim of the study is to outline an approach that is more useful to $\mathrm{VI}$ people and making web pages more accessible. such as different types of software used for better e-accessibility improve the functional capacities of VI people. These tools provide an opportunity to communicate, thus helping to gain access to education and skills needed for gainful employment.

It is proposed in this study that a conceptually abstract view should be taken of an accessible learning environment; and describes a new process of allowing the translation of a conceptual model into a specific code adapted to the user's individual learning context. The translation process corresponds to a personalisation process that supports people with disabilities in learning.

Descriptive method is used. The research data is gathered by a review of literature, and by the interviews with GETEM project executives.

Content analysis.

A survey was conducted to fulfil the objectives of the research where the webpages were written in HTML and CSS algorithms to find webpages according to the user's pattern of interests.

Observation of the assigned activities. Before participants began their eight trials, they spent a few minutes using the system in a simple virtual environment. change to transform schools and teaching practices and assist in learning for VI people.

- ICT can empower people with disabilities and assist in creating skills that increase education to gain fulfilling employment.

- Proposed a new approach for the development of accessible e-Learning environments consisting of three phases: design, implementation, and validation.

- The meta-model for accessible e-Learning systems helps to automatically generate accessible content, and the conformance of the content, to e-Learning for VI people.

- Library and information centres should have facilities for individuals with visual disabilities to facilitate the access of information to disabled people in any format.

- As a result, the advances in the present services types that libraries provide for different user groups in Turkey are hopeful.

- People with disabilities will have increased chances of integration into the educational system, labour market or in society, whicht are the essential parts of any e-Learning solution.

- Direct implementation of the preference theory approaches are disappointing.

- The results with NSGA-II are very encouraging.

- Locomotion interface users reasonably improved their performances (e.g., the time or the number of steps taken over the period of the eight trials). 
MD MAHFUZ ASHRAF ET AL.

Continued

\begin{tabular}{cll}
\hline Author(s) & Aims/Objectives of Study & Methods \\
\hline $\begin{array}{c}\text { Bujacz et al. } \\
\text { (2011) }\end{array}$ & $\begin{array}{c}\text { The study investigates the } \\
\text { development of an algorithm for } \\
\text { representation of 3D scenes can be } \\
\text { used for and electronic travel aid } \\
\text { system for VI people. }\end{array}$ & $\begin{array}{l}\text { Experimental study. Various machines } \\
\text { were 3D-enabled, and depth } \\
\text { measurement were used to conduct } \\
\text { the experiment. }\end{array}$ \\
$\begin{array}{c}\text { Pascual et al. } \\
\text { (2014) }\end{array}$ & $\begin{array}{l}\text { The study observes the mood of a } \\
\text { group of users when they interact } \\
\text { with two parallel websites and } \\
\text { evaluates the collected information. }\end{array}$ & $\begin{array}{l}\text { Experimental study. Thirteen } \\
\text { participants in different categories } \\
\text { were tested. The mood of the users } \\
\text { and their interaction efficiency, } \\
\text { effectiveness and satisfaction were } \\
\text { recorded as they encountered }\end{array}$ \\
& & several web content accessibility \\
& barriers.
\end{tabular}

Ramos \& de Study of schools for the education of Andrade the blind and partially sighted (2014) students that concentrated on human and material resources.

Carrière (2012) This study investigates how VI students related with their classmates and teachers during training aided by educative informatics.

Kabátová et al. To describe the experience of teaching (2012) VI children at a special secondary school.

Fernandes et al. To present a platform to handle and (2012) provide geographic information, including accessibility oriented features.

A survey was adopted as a method of data collection.

Interviews of 10 students with visual disabilities to highlight the significance of this cooperation.

Used robotic toys (Bee-Bot) and programmable robotic kit (LEGO We Do) with 5 groups ranging from 10 years old to 15 years old.

The GIS platform provides information to blind users, assisting their navigation and giving alerts of nearby points-of-interest or obstacles.

This study is based on semistructured interviews and qualitative methods, which are applied to concerns of VI learners.

By selecting and observing 50,000 VI users across several aspects of social media use, including Facebook activities, the content produced, and the structural characteristics of their friendship networks.
Research Findings

- Both groups of trial participants performed with better than 90\% accuracy in estimating direction and depth of the obstacles.

- There is a clear correlation in the results when the users made comparisons between the two test websites.

- Most teachers are proficient in computer use (98\%).

- All teachers have significant experience in educational context, yet with fewer years of teaching students with visual disability.

- Different transcription outlined different results. Some results are positive and some are negative.

- The activities with a programmable toy Bee-Bot are suitable even for the secondary school pupils especially for those who are VI.

- If the GIS area is to be covered and described in detail, it is possible to provide better information more easily to the VI user.

- In addition, it is possible to provide proximity information (e.g., to a streetlight or pedestrian crossing) to assist with navigation in the $\mathrm{VI}$ person's daily life.

- Specific design for VI learners does not yet exist. The need for educational content using AT application is urgent.

- The findings show that the Facebook users who are VI participate in all the main social activities (e.g., status updates, comments or likes, and receive on average more feedback from others).

- Other findings show the necessity to develop apps for VI users that can automatically detect them; this data analysis has revealed characteristic keywords related to visual impairment and shows that some of VI people's activities, such as photo uploads, are related to specific applications used by them. 


\begin{tabular}{ll}
\hline Author(s) & Aims/Objectives of Study \\
\hline $\begin{array}{l}\text { Pal \& } \\
\text { Lakshmanan } \\
\text { (2012) }\end{array}$ & $\begin{array}{c}\text { To study the role of AT to assist } \\
\text { participation of VI people in finding } \\
\text { employment in the labour market. }\end{array}$ \\
& \\
& \\
S.L. Ludi et al. & To access JBrick (a software project to \\
(2014) & assist students with visual \\
& impairment) that provides an \\
& accessible (Lego Mindstorms NXT) \\
programming environment, which \\
can be used by VI students.
\end{tabular}

Strumillo (2010) To study and review the barriers, problems and present technologies for assisting blind people in outdoor mobility.
Describes the specific accessibility features of programming environment by Lego Mindstorms NXT that assists VI students.
Examine the roles of AT in labour market participation of people with physical disability.
Discussions on space perception related to mobility of VI people and then qualitatively exploring the concepts of cognitive mapping, way finding and navigation.
Buzzi et al.

(2012)
To study the accessibility barriers that blind people face when they interact with learning apps or educational content on touch screens on mobile.
Special attention to touch screen technology that is specifically oriented to visual information.
Research Findings

- The in-depth interviews identified the value and potential that AT has for VI people to participate in the labour market, this study suggests ways to provide greater access to subsidised or open source AT.

- The interviews reveal that AT enhances economic and social development, and how it instills hope for the inclusion of $\mathrm{VI}$ people by providing greater accessibility to AT.

- The study finds that JBrick can potentially assist students with visual impairment using Lego Mindstorms NXT robots programming.

- Further study is required to improve the JBrick technology to increase the blind users' experience and to make it more interesting to recommend use to their peers.

- Although there is a significant advancement in accessibility to aid the blind by using devices such as mobiles, PCs, OCR, which are costly, there has been no satisfactory advancement as yet in AT for the blind for better outdoor mobility; this is due to the lack of specific design aspects for $\mathrm{VI}$ people of such devices.

- Since every VI person has different mobility issues, it is important to develop devices, such as sensors, GPS receivers, or electronic compasses to meet their specific individual needs and cater to specific mobility issues.

- The study suggests that when designing a mobile app the following essential aspects should be considered:

- User interface design of an app with standard buttons, checkboxes or labels to make the assistive app more interactive.

- Add voice command functions to enhance apps functions, such as reading contents, checking status, audio listening.

- Add personalised interactive modalities to the apps. 
MD MAHFUZ ASHRAF ET AL.

Continued

\begin{tabular}{|c|c|}
\hline Author(s) & Aims/Objectives of Study \\
\hline $\begin{array}{l}\text { Kulyukin \& } \\
\text { Kutiyanawala } \\
(2010)\end{array}$ & $\begin{array}{l}\text { To examine what design requirements } \\
\text { are important to build assistive } \\
\text { shopping systems, and analyse and } \\
\text { compare the approaches for } \\
\text { available solutions to help designers } \\
\text { who can learn from this study to } \\
\text { develop relevant AT shopping } \\
\text { systems. }\end{array}$ \\
\hline
\end{tabular}

S. Ludi \& Reichlmayr (2011)

Jadán-Guerrero (2014)

Armano et al. (2014)

Singh \&

Moirangthem

(2010)
Methods

To develop a grocery shopping system by addressing the problems faced by blind people while using existing assistive shopping systems. develop relevant AT shopping systems.
To study the tools, materials and environments that increase the accessibility and participation of $\mathrm{VI}$ students into robotics and computing programming.
Used robotics programming tools with the accessibility focus for participants with different degrees of visual impairment.
Research Findings

- Although several systems exist in supermarkets to assist VI people in their shopping experience, none of those meet all the their needs or wants.

- Existing solutions have improved awareness of store navigation, product search and product identification; however, these solutions are not as effective, useable or as versatile as more recently developed AT devices; interestingly, blind buyers show less interest in purchasing newer and more useable devices as they are likely to retain devices that they are already familiar with

- Whether a learning facility offers computer science courses or not, VI students are equally interested in participating in such courses, and the expansion of these courses may increase their participation in computing courses at high school level.

- An increased interest and confidence was seen when VI students participated with sighted peers in follow-up activities.

Installed the software in approximately 1,000 laptops donated by program 'Misión Manuela Espejo'. government on how AINIDIU (a computer-based technology designed for blind and VI children) can assist in the training process of blind or VI children to develop higher level computer skills.

To study the accessibility problems as well as the advantages of the available instruments, methods or software that are provided for $\mathrm{VI}$ students in university enivronments, using teaching materials that include mathematical content.

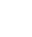

University teaching materials for using It is found that: software enabled processes for learning by VI students. speech synthesis and hotkeys.
- The study found that AINIDIU technology can create an entertainment-education strategy, which improves the learning ability and the user experience for blind and $\mathrm{VI}$ children.

- Software such as LeanMath is more accessible for VI people to use its graphical interface; with MathType accessible through

- Software such as LaTex, BlindMath and Texeasier are highly accessible and useable for VI people.

- LAMBDA is a good solution for VI people who need to write math formulas.

- The study shows that the library is an important source of reading materials; a few libraries provide services for VI students.

- Libraries are in need of special initiatives to provide services for VI students. 
Continued

\begin{tabular}{|c|c|c|c|}
\hline Author(s) & Aims/Objectives of Study & Methods & Research Findings \\
\hline $\begin{array}{c}\text { Pathy et al. } \\
\text { (2011) }\end{array}$ & $\begin{array}{l}\text { To study the effectiveness, practicality, } \\
\text { adaptability, advantages and } \\
\text { disadvantages of Trekker (a } \\
\text { GPS-enabled technology) that aids } \\
\text { VI people to access information in } \\
\text { real-time about their location, } \\
\text { surroundings and available guidance } \\
\text { (in Kuala Lumpur, Malaysia). }\end{array}$ & $\begin{array}{l}\text { A tool named 'Trekker' that uses GPS- } \\
\text { and audio-guided GPS map } \\
\text { technologies together to aid VI } \\
\text { people. }\end{array}$ & $\begin{array}{l}\text { - The study shows that Trekker can } \\
\text { be used to complement other } \\
\text { existing traditional visual aids } \\
\text { such as a white cane or a guide } \\
\text { dog; Trekker alone cannot } \\
\text { identify any upcoming obstacles } \\
\text { for the VI user. } \\
\text { - Inaccuracy of the GPS makes } \\
\text { Trekker less accurate. } \\
\text { - Not easy to use for beginners. } \\
\text { - A complete study is required to } \\
\text { assess the optimum practicality } \\
\text { and adaptability of Trekker. }\end{array}$ \\
\hline $\begin{array}{l}\text { Samaniego et al. } \\
\text { (2012). }\end{array}$ & $\begin{array}{l}\text { To provide recommendations to } \\
\text { improve information policies and } \\
\text { strategies for using ICT to educate } \\
\text { people with disabilities and } \\
\text { incorporate issues related to } \\
\text { disability. }\end{array}$ & $\begin{array}{l}\text { Interpretative paradigm with a } \\
\text { qualitative approach. }\end{array}$ & $\begin{array}{l}\text { - Participation is oriented toward } \\
\text { improving information policies, } \\
\text { strategies for access to and use } \\
\text { of ICT to educate people with } \\
\text { disabilities. } \\
\text { - An inclusive educational system } \\
\text { has been established for people } \\
\text { with disabilities. }\end{array}$ \\
\hline $\begin{array}{c}\text { Anuar et al. } \\
\text { (2015) }\end{array}$ & $\begin{array}{l}\text { Improving accessibility for people with } \\
\text { disabilities travelling to and booking } \\
\text { hotel accommodation; better access } \\
\text { would result in people with } \\
\text { disabilities travelling more. }\end{array}$ & $\begin{array}{l}\text { Researchers adopted qualitative } \\
\text { in-depth interviews as the main } \\
\text { method for this study among } \mathrm{VI} \\
\text { people. }\end{array}$ & $\begin{array}{l}\text { - Results are classified into two } \\
\text { points of view that consist of the } \\
\text { use of a Braille menu and a } \\
\text { Braille guest directory book. } \\
\text { - By the use of a Braille menu, VI } \\
\text { people tend to rely solely on the } \\
\text { assistance of sighted people. } \\
\text { - Most VI people who are } \\
\text { travelling will be accompanied } \\
\text { by a sighted person/people, but } \\
\text { may also use various types of } \\
\text { assitive technology that are } \\
\text { available. }\end{array}$ \\
\hline $\begin{array}{c}\text { Bonnah et al. } \\
\text { (2010) }\end{array}$ & $\begin{array}{l}\text { To promote access to new ICT and } \\
\text { systems for people with disabilities, } \\
\text { including the internet with an } \\
\text { emphasis on the accessibility of ICT. }\end{array}$ & $\begin{array}{l}\text { Qualitative interviews and focus } \\
\text { groups were used alongside } \\
\text { quantitative questionnaires to } \\
\text { address the main findings of the } \\
\text { study. }\end{array}$ & $\begin{array}{l}\text { - Some VI people identified lack of } \\
\text { books in accessible formats; } \\
\text { some were faced with barriers } \\
\text { such as the lack of assistive } \\
\text { technologies. } \\
\text { - ICT, however, identified a need } \\
\text { to overcome such situations. }\end{array}$ \\
\hline $\begin{array}{l}\text { Borg et al., } \\
\text { (2011) }\end{array}$ & $\begin{array}{l}\text { To clarify the limitations and } \\
\text { opportunities of the Convention on } \\
\text { Rights of People with Disabilities for } \\
\text { formulation of AT policies and } \\
\text { implementation of strategies. }\end{array}$ & $\begin{array}{l}\text { The study was conducted by } \\
\text { systematic literature review and } \\
\text { then content analysis of the selected } \\
\text { articles. }\end{array}$ & $\begin{array}{l}\text { - People with diability are in need } \\
\text { of AT for many other purposes } \\
\text { besides personal mobility. } \\
\text { - AT measures should be } \\
\text { implemented to protect the } \\
\text { rights of people with disabilities. }\end{array}$ \\
\hline Calder (2010) & $\begin{array}{l}\text { Addressing the 'device' and the } \\
\text { importance of some special devices } \\
\text { to assist VI people. }\end{array}$ & Qualitative and informative analysis. & $\begin{array}{l}\text { - A segment described a spatial } \\
\text { sensor using echolocation } \\
\text { bioacoustics technology for VI } \\
\text { people. } \\
\text { - Emphasised the ease of learning } \\
\text { and use of such devices. } \\
\text { - Increased adaptability and } \\
\text { flexibility for all AT for people } \\
\text { with disability }\end{array}$ \\
\hline
\end{tabular}


MD MAHFUZ ASHRAF ET AL.

Continued

\begin{tabular}{|c|c|}
\hline Author(s) & Aims/Objectives of Study \\
\hline $\begin{array}{c}\text { Kane et al. } \\
(2011)\end{array}$ & $\begin{array}{l}\text { To introduce and describe access } \\
\text { overlays as a set of new techniques } \\
\text { that enable blind people to explore } \\
\text { and interact with applications on } \\
\text { interactive tabletops. }\end{array}$ \\
\hline
\end{tabular}

Aziz et al. (2011). To investigate the accessibility of websites for the disabled user

Mothiravally

et al. (2014)

To understand the attitudes and perceptions of VI travellers in a Malaysian context.
Methods

Develop three access overlays and compare these with Apple's VoiceOver.

Research Findings

- Introduce new accessible touch screen applications.

- Using touch screen interfaces remains a significant and sometimes intimidating challenge for blind people.

- Improving the useability, accessibility, and approachability of touch screens

Automatic web evaluation tool called EvalAccess 2.0 used accessibility evaluation of a total of 100 websites; accessibility analysis was conducted.

Qualitative method (focus group interview), based on an intrepretivist approach.
- To ensure the right to access the website for people with disability.

- Suggests to the software developer to provide greater access to disabled people.

- Most VI travellers are unaware of assistance available for disabled travelling because of a lack of communication and information; websites for such information are also not disabled-friendly.

- The infrastructure of outdoor and indoor spaces often does not have properly installed tactile and easily accessible signage and/or audible traffic signals for VI travellers.

- Physical obstructions, such as lamp posts, uncovered drains, inappropiately parked vehicles, or the general population using disabled parking spaces for business or other personal purposes also cause barriers to VI travellers.

- VI travellers sometimes do not receive respectful and efficient service from hotel or tourism services staff.

Note: $\mathrm{AT}=$ assistive technology; ICT = information communication technology; $\mathrm{VI}=$ visually impaired . 